\title{
能登半島地震被災集落・道下の住宅復興の実態（震災後 2 年の復興過程） \\ - 道下集落の伝統的空間構成と復興住宅の屋敷地利用パターンの特徵に着目してー THE REALITIES OF HOUSING RECOVERY SEEN FROM VILLAGE CHARACTERISTIC AND SITE CONDITIONS (Revival process until struck 2 year) \\ For the Noto peninsula earthquake struck, Touge village

\author{
山崎 寿 - *, 中川和 樹** \\ Juichi YAMAZAKI and Kazuki NAKAGAWA
}

\begin{abstract}
We clarified the following points in case of Touge village, Wajima city where is near to the hypocenter and has sustained great damage in the stricken area of Noto earthquake in March of 2007.

1. We clarified the characteristics of the spatial composition of Touge, consisting of about 300 houses, based on analysis of the neighborhood, the road pattern and site characteristics.

2. We clarified the characteristics of the reconstruction process and the rebuilding houses in Touge

3. We clarified the characteristics of the housing location, site planning, rebuilding houses and site use.
\end{abstract}

\section{Keywords : Noto Peninsula earthquake Struck village Housing recovery \\ Site use Underpopulated area Aging \\ 能登半島地震，被災集落，住宅復興，敷地利用，過疎地域，高齢化}

\section{1. 研究の目的と方法}

\section{$1-1$. 本稿の目的}

本稿は、2007 年能登半島地震の最大の被災集落である輪島市門前 町諸岡地区道下 (とうげ) 集落を対象とする集落研究・震災復興研 究の第 2 報である。先の論文注1) では、能登半島地震の被災地域の 過疎高齢化の実態と研究対象である道下集落の位置づけ、地域特性 （地域の社会的・歴史的・空間的な特徵）について整理し、震災後 1 年半時点での震災復興の概要と復興計画の特徴を報告した。

本稿では、道下集落の地域特性注 2) のうち、空間的な特徵に着目

し、以下の研究課題を設定して研究を進める。

(1) 道下集落の立地、形態、形成過程の特徴を整理すると共に、集 落の伝統的な空間構成と屋敷地利用の特徵を明らかにする。

(2) 震災後 2 年時点での住宅復興の実態を明らかにする。

(3) 集落の伝統的空間構成、特に江戸時代に計画的に形成されたエ リアである本町通り沿道の屋敷地利用の基本パターンと住宅 復興の対応を明らかする。

\section{1-2. 研究の方法}

上記(1)〜 (3)の研究課題を明らかにするために、2007 年 5 月から 2009 年 8 月にかけて 10 回の現地調查注 3 ) を実施した。

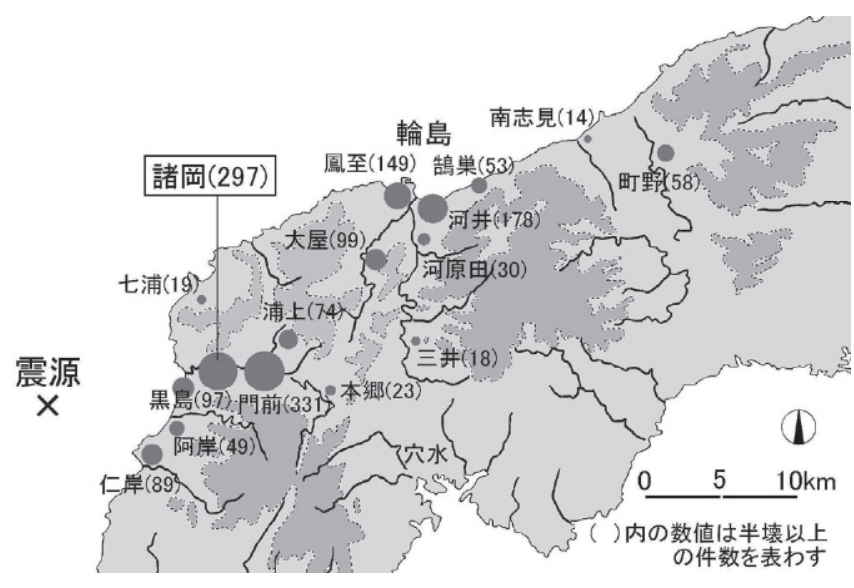

備考：輪島市都市整備課（2008 年 7 月 8 日時点データ）より作成 図 1 能登半島地震被災地区の分布（輪島市旧町村別：地形対応）

特に、集落の空間構造、住宅復興の実態把握については、震災直 前（2006 年）の空中写真から 1000 分の 1 の集落図を作成し、震災 直後、半年後、最初の正月、 1 年後、 1 年半後、 2 年後の定期的な 現地調査（屋敷地・建物配置の実測調查と図面採取、住民からの空
* 神戸大学大学院工学研究科 准教授・博士 (工学)

** 神戸市役所 修士 (工学)
Assoc. Prof., Dept. of Architecture, Graduate School of Engineering, Kobe Univ., Dr. Eng. Kobe City Government Office, Master of Engineering 
間利用と敷地管理状況のヒアリング）を行っている。また被苂後の 住宅復興については、被災状況（全壊、半壊等：輪島市都市整備課 の分類）、住宅復興の手法（再建、修理）、住宅復興時期（震災後半 年、 1 年、 2 年) 、被災者の家族構成（世帯主年齢、家族人数）等と の対応関係を調查した。

\section{2. 道下集落の伝統的空間構造}

\section{2-1. 集落の立地と形態の特徵}

まず、本研究の対象集落である輪島市門前町諸岡地区道下集落の 空間的特徴についてまとめておきたい。

図 1 に、輪島市の地形と被災地の分布を旧町村を単位に示した。 今回の地震の震源は門前町の西方沖 10 キロの地点で、被災地は東 に延びる八ヶ川沿いの断層にそって分布している。最も被害が大き かったのが、震源地に近い八ヶ川下流の諸岡地区である。さらにこ の断層が延びる輪島市臨海部、穴水町中心部の被害も大きかった。

写真 1 に本研究の対象地域周辺の空中写真を示したが、被災集落 でもそれぞれ集落の立地や形態が異なっている。鹿磯（かいそ）集 落は、沿岸に立地する漁村集落で、黒島集落は、2009 年 6 月に重 要伝統的建造物群保存地区に選定された沿岸集落である。注4)道下 集落は、一部海に面しているが漁業従事者はおらず、八ヶ川河口の 平地部に立地する農村集落である。

図 2 に、道下集落、鹿磯集落、黒島集落の集落形態の模式図と代 表的な宅地割と敷地形状を示した。集落形態についてみると、3 集 落とも塊村であり、集落空間の軸となる主要な骨格道路の存在が確 認できる。道下集落の中央の骨格道路は他と比較して幅員が広く、 それに取り付く屋敷地も大規模であるのが大きな特徴である。宅地 割、屋敷地の規模、形状についてみると、道下集落の中央部の屋敷 地が大規模で整然とした宅地割であることがわかる。ちなみに図 2

（下段）に示した道下集落の骨格道路沿いの屋敷地は、1386 $\mathrm{m}^{2} 、$ 鹿磯集落は $491 \mathrm{~m}^{2} 、$ 黒島集落は $520 \mathrm{~m}^{2}$ である。

\section{$2-2$. 集落の伝統的空間構成}

次に道下集落の集落レベル、屋敷地レベル、住宅レベルの空間構 成の特徵について整理する。

集落域の空間構成 ; 集落域の空間構成は、東西に延びる本町通り を軸に、通り沿いに規則的な宅地割がなされた屋敷地が集合して居 住域が形成されている。そして東西方向に流れる八ヶ川とその支流 で南北方向に流れる護摩堂川の周辺に農地、その背後に山林・共有 林が広がっている。集落域の南側の最奥地は、戦後の開拓地である 大生（おはえ：写真 1 南側）、別荘地のまんだら村が立地する。

集落の骨格（道）の構成；道下集落の居住域の骨格なっているの は、東西に走る宮町通り、本町通り、北町通りの 3 本の通りである。 3 本の道は「マチドオリ」とよばれ、南北方向には、「ナカシャ」 とよばれる小道が配されている。中でも集落の中心軸である本町通 りは、江戸時代に計画的に造られた道路である。

形成時期に着目した町内会の構成：図 3 に道下の 11 の町内会の 構成を示した ( 2 つ自治会は公営住宅)。形成時期から町内会の構 成をみると、諸岡比古神社周辺の元町、宮町、新鉄川町が近世以前 の開発エリアで、東町、中町、西町と北町は江戸時代の大火後に整 備された計画村、明治以後に発展した大蔵町、栄町に分類でき、以

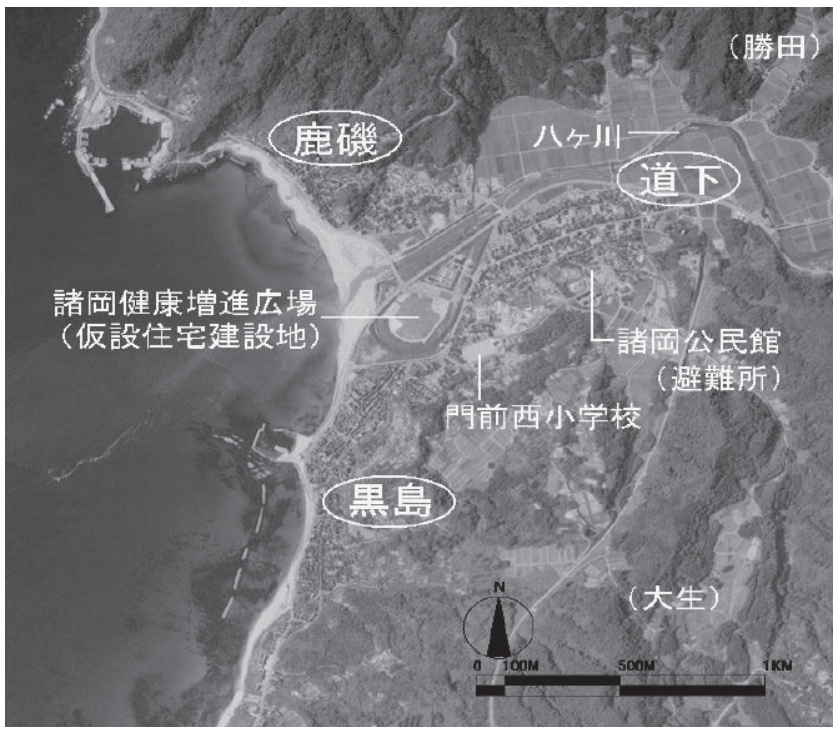

日本地図センター「輪島 1/30000 CB2006X-C8-2」（2006 年 6 月 2 日 撮影）をもとに作成

写真 1 旧門前町諸岡地区道下集落とその周辺（空中写真）

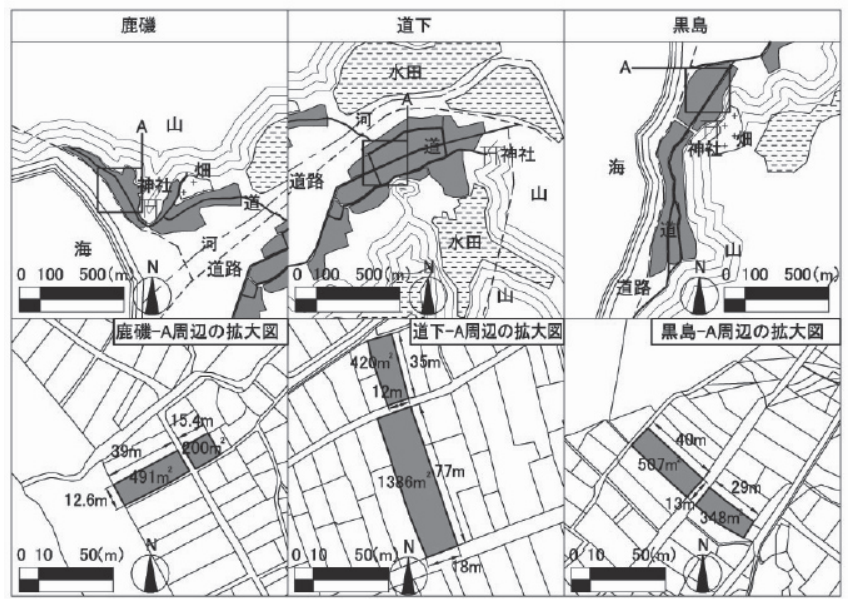

図 2 道下・鹿磯・黒島の集落形態・宅地割（模式図）

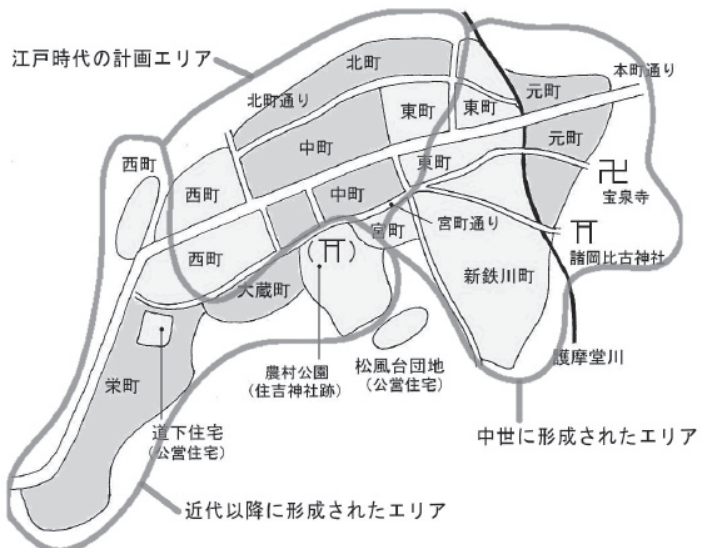

図 3 形成時期からみた道下集落の町内会の構成（模式図）

下で述べるように宅地割・敷地形状、敷地面積や土地利用にそれぞ れ特徴がある。 


\section{2-3. 屋敷地の空間構成}

道下では、屋敷地全体をヤシキチと呼ぶ。江戸 時代の計画エリアでは屋敷地の空間構成には基本 的なパターンがある（図４（ア）参照)。

本町通りに面する屋敷地は、間口が平均 15〜 $16 \mathrm{~m}$ (最大で $30 \mathrm{~m}$ 以上、最小で約 $10 \mathrm{~m}$ )、奥行が 平均 $62 \sim 63 \mathrm{~m}$ (最大で約 $90 \mathrm{~m}$ 、最小で $30 \mathrm{~m}$ 未満) の短冊型の敷地形状をしており、コウマチ、ヤシ キ、セド、オオセドという 4 つの空間より構成さ れている。コウマチは本町通りと母屋に挟まれる 空地である。コウマチがあるのは、江戸時代に計 画的に形成されたエリア内で、市の開催場所とし て設けられたと推測されている（諸岡村史及び鄉 土史家からのヒアリングより)。ヤシキは母屋・付 属棟（離れ、蔵、納屋）が建つ空間で、セドはヤ シキの裏にある菜園、庭、オオセドはセドの奥で 北町通りに面寸る空間である。昭和期以降、才オ セドが宅地化され、分家や集落内からの新宅に売 却される場合もあった（図4（イ）参照）。付属棟 の一つである離れとは、母屋の裏に設けられた居 室のことを指し、元々は畜舎や作業小屋であった。 1965 年以降、それらは改築・居室化され余裕室と して機能し、盆、正月に帰省する兄弟や子供が利 用した。

本町通り沿いには整形の屋敷地が多く、特に $1000 \mathrm{~m}^{2}$ を越える大規模なものが集中している。 (図 5 参照) 北町通り沿いの屋敷地は、 $500 \mathrm{~m}^{2}$ 程 度の短冊型の形状のものが多いが、敷地内に菜園 はない。また宮町通り北側の敷地は整形で $500 \mathrm{~m}^{2}$ 程度、通りの南側は地形条件もあって、不整形で $1000 \mathrm{~m}^{2}$ 以上の屋敷地となっている。敷地規模が小 さい場合でも、母屋と付属棟（蔵、納屋）からな る建物構成は同じであるが、離れをもつことはな い。また、形成時期の古い元町や新鉄川町、明治 以降に発展した大蔵町、栄町の屋敷地には、敷地 内に菜園や離れがない場合が多い。

\section{3，道下集落における被災状況と住宅復興 $3-1$. 住宅の被災状況}

図 6 は、道下集落における住宅の被災状況、表 1 は、住宅の被苂状況を現住 (常時居住) - 非現住 (家財は残しているが他に住居があり常住してい ない）世帯別に示したものである（罹災判定は母. 屋の被害を表す)。被災時の道下の世帯数は 319 で、現住世帯が 244、非現住世帯が 55、公営住宅 世帯が 20 である。公営住宅は 1970 年代に建てら れた木造平屋の道下住宅が 8 戸、 90 年代に建てら れた木造 2 階建ての松風台住宅が 12 戸でいずれ も一部損壊であった。

現住世帯の住宅の被災状況をみると、大規模半

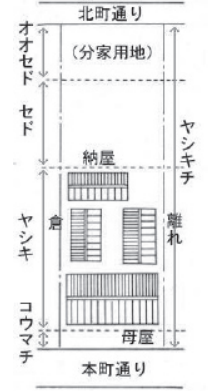

0 5 - $10 \mathrm{~m}$

(ア)

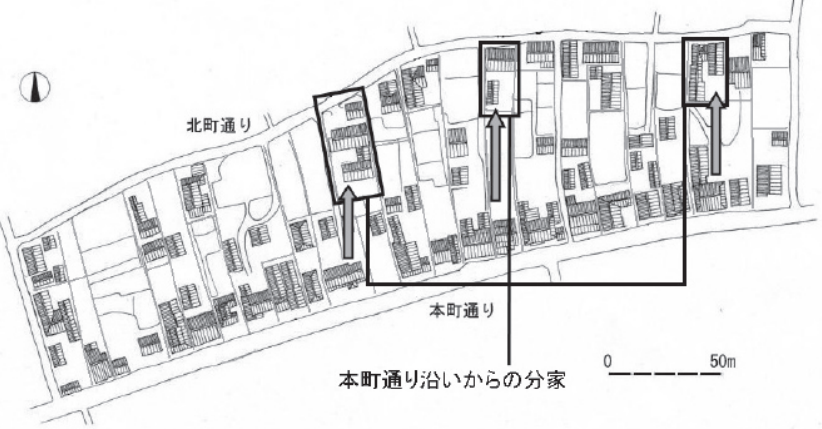

(イ)
図 4 屋敷地の空間構成の基本パターンと本町通りの沿道土地利用

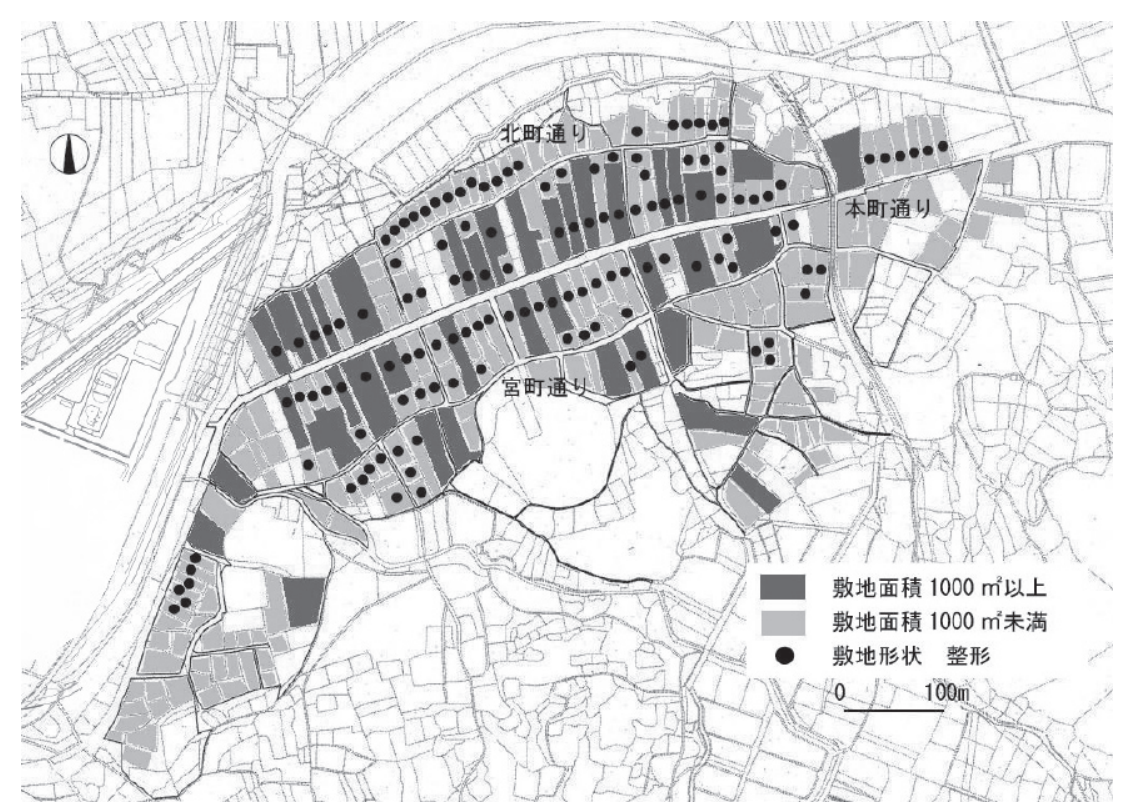

図 5 敷地形状と敷地面積の分類

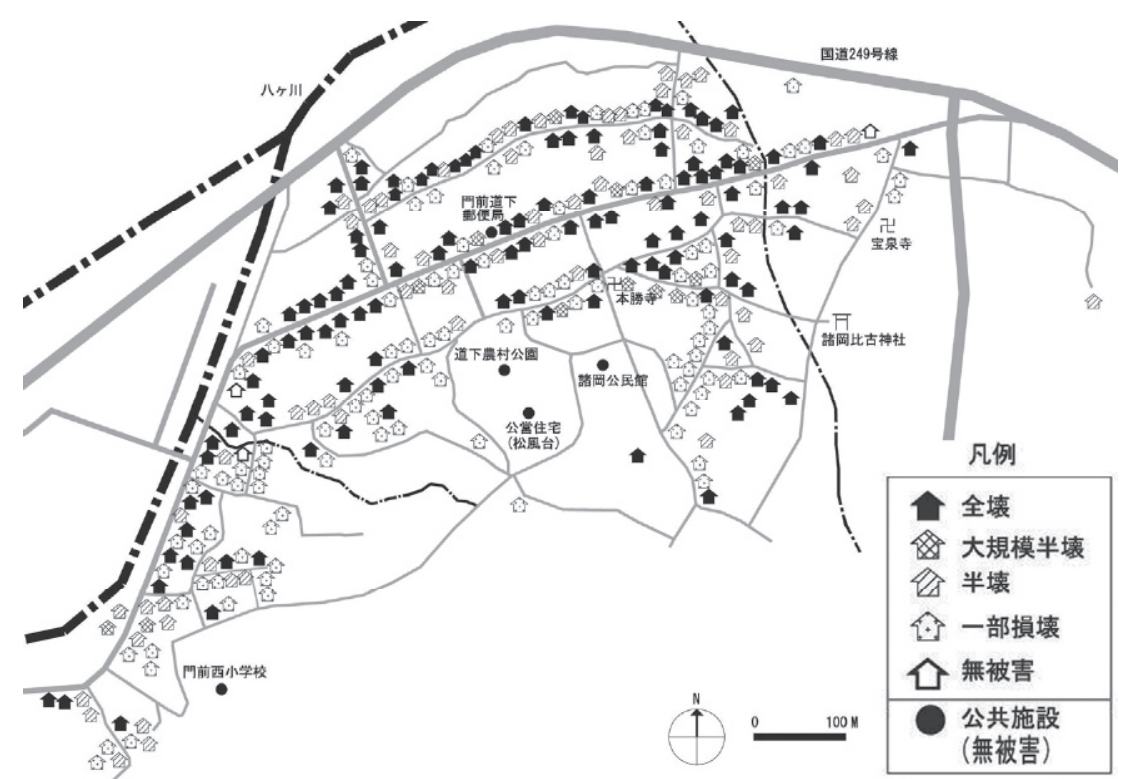

*輪島市都市整備課の資料をベースに現地調查で補足し、作成した。

図 6 道下集落における住宅・建物の被災状況（2007.3） 
表 1 道下の町内会別被苂状況

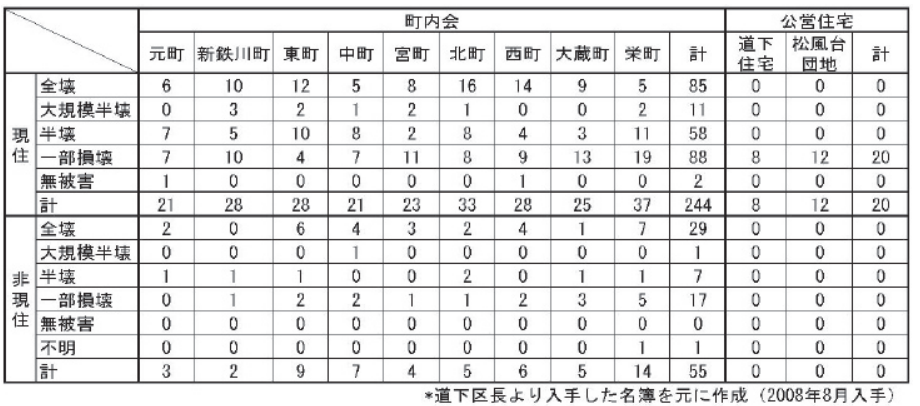

表 2 罹災判定と建物の建設年の関係

\begin{tabular}{|c|c|c|c|c|c|c|}
\hline & \multicolumn{4}{|c|}{ 建物の建設年 } & \multirow{2}{*}{ 計 } \\
\hline & & S34年以前 & $S 35 \sim 56$ 年 & S57年以降 & 不明 & \\
\hline \multirow{3}{*}{$\begin{array}{l}\text { 罹 } \\
\text { 災 } \\
\text { 判 } \\
\text { 定 }\end{array}$} & 全壊 & 43 & 27 & 11 & 4 & 85 \\
\hline & 大規模半猿 & 3 & 5 & 2 & 1 & 11 \\
\hline & 半壊 & 14 & 31 & 10 & 3 & 58 \\
\hline & 計 & 60 & 63 & 23 & 8 & 154 \\
\hline
\end{tabular}

資料 輪島市都市整備課内部資料一固定資産台帳より作成
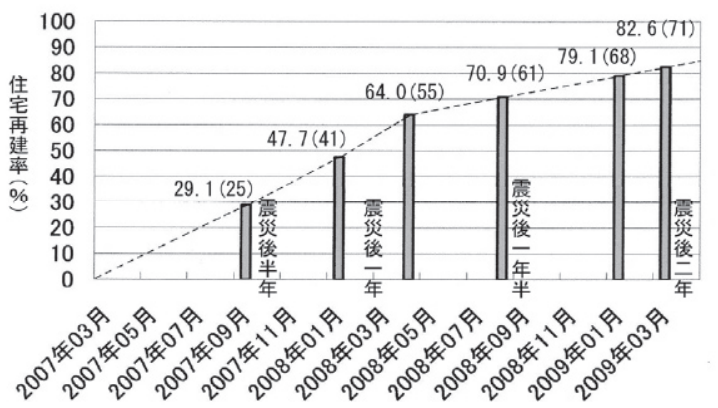

括弧内の数值は戸数を表す。

図 7 住宅再建の推移
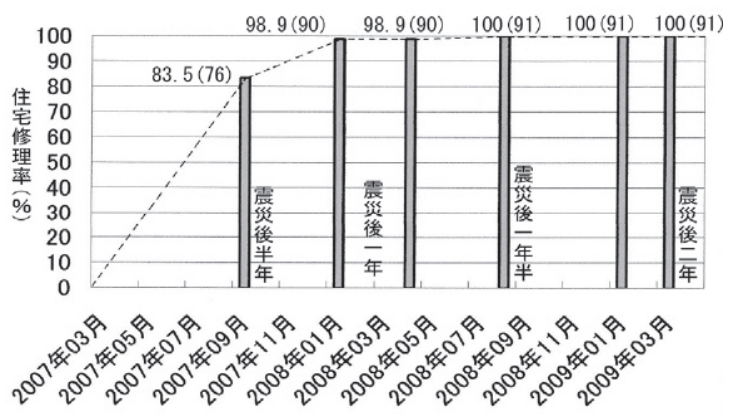

括弧内の数值は戸数を表す。

図 8 住宅修理の推移

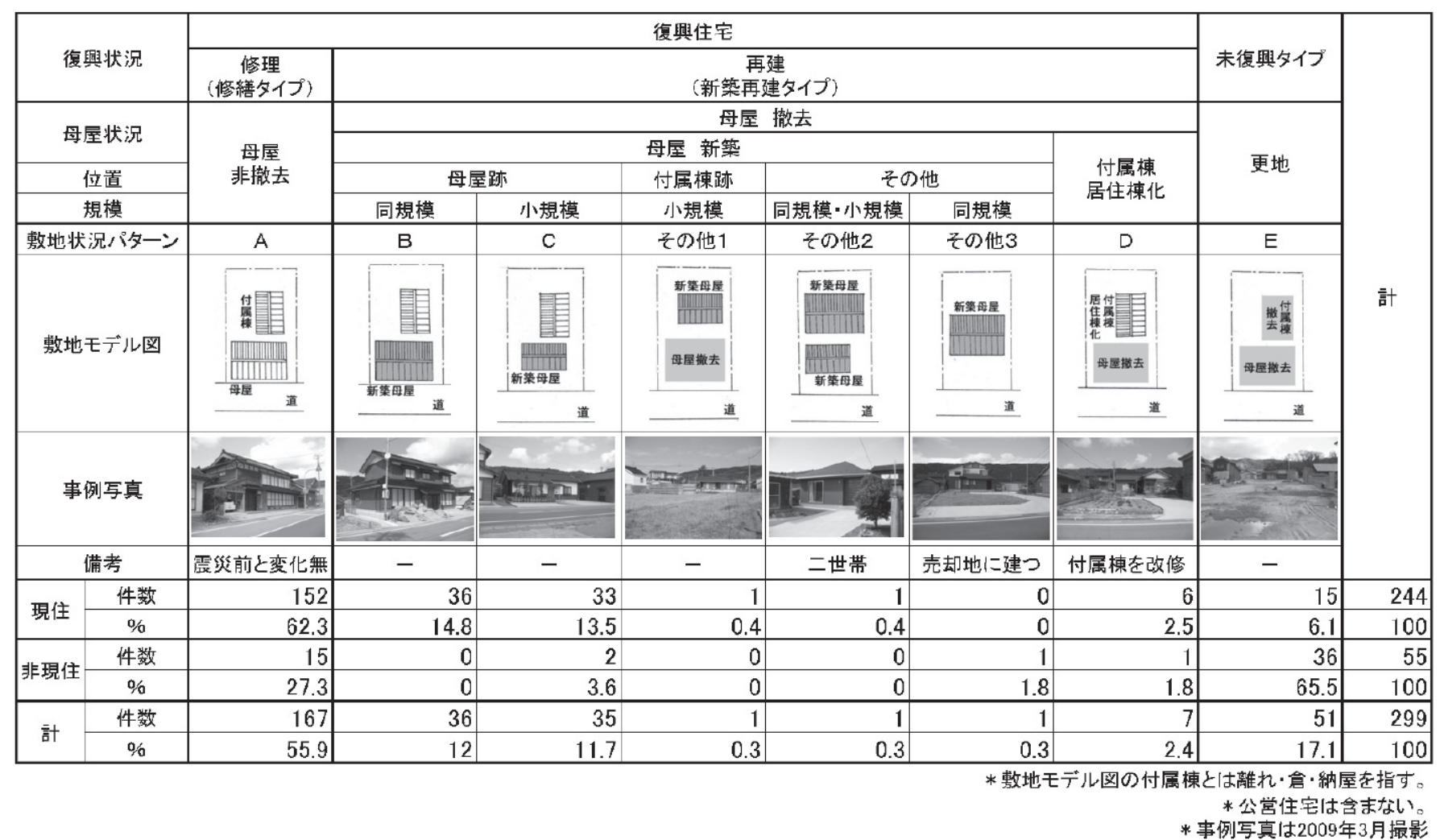

図 9 震災 2 年後の住宅復興タイプー屋敷地の従前土地利用と復興住宅の対応と住宅規模からの分類 
壞以上の住宅 96 戸、半壊が 58 戸、一部損壊が 88 戸で、無被害は 2 戸だけである。非現住世帯の住宅は大規模半壊以上の住宅が 30 戸、半壊が 7 戸、一部損壊が 17 戸、不明が 1 戸となっている。ま た罹災判定と建物の建設年の関係をみると、全壊した母屋 85 戸の 内、半数以上の 43 戸が昭和 34 年以前に建てられたものであった。 (表 2 参照)

\section{3-2. 住宅の復興状況}

図 7 、図 8 は、住宅の復興状況を時系列で整理し、復興率の推移 を示した（現地での目視調査による）。住宅の復興については、被 災住宅を除去して新築する住宅再建と、被災住宅を修理する住宅修 理に分類した。

住宅再建についてみると、被災半年時点での再建は 25 戸、正月 時点で 41 戸、被災 1 年で 55 戸、 1 年半で 61 戸、 2 年で 71 戸とな っている。住宅修理の場合、被苂半年時点では 76 戸、正月時点で 90 戸、被災 1 年で 90 戸、 1 年半で 91 戸となり住宅復興は終了した といえる。再建と修理では復興のスピードが異なり、半年後で再建 は $30 \%$ 、修理は $84 \%$ 、正月前で再建は $50 \%$ 、修理は $99 \%$ 、1 年後 では再建は $64 \%$ 、修理は $99 \%$ 、1 年半後で再建は $70 \%$ 、修理は $100 \%$ 、 2 年後で再建は $83 \%$ 、修理は $100 \%$ となっている（図表中、2008 年 1 月とあるのは集計時で、調査は 2007 年 12 月 10 日)。

\section{4 、屋敷地の従前土地利用と復興住宅}

\section{4-1. 屋敷地の従前土地利用と復興住宅の対応とその分類}

図 9 は、現住世帯、非現住世帯別に、復興住宅を分類したもので ある。全住宅（244 戸）のうち、震災 2 年時点で復興した住宅は、 229 戸、約 9 割で、空地となっている敷地が 15 力所（他地域一転出 した世帯のものが 3 力所、災害住宅に入居した世帯のものが 2 力所、 未再建が 10 カ所）ある。非現住世帯の住宅についてみると、再建さ れた住宅は 4 戸であるが、いずれも他に売却された後で再建された ものであり、自分の居住用に再建した事例はない。

先に述べたように、道下の伝統的な住宅は、間取りや屋敷地の利 用において、一定の規則性をもっていた。ここでは震災前の母屋と 復興住宅の位置、及び従前住宅との規模の比較から、震災後の復興 状況を（A)から（E）の5 パターンとその他に分類、整理した。復 興住宅は、被災住宅を修理した「修理（修繥タイプ）」（修理：A）と 被災住宅を除去して新築した「再建（新築再建タイプ）」に分類でき る。再建タイプは更に、従前の母屋の位置に同規模の母屋を新築す るタイプ(同規模再建 : B)、小規模の母屋を新築するタイプ (小規模 再建: C)、撤去した母屋の跡を空地にし、その裏の納屋・離れ等を修 繕・居室化するタイプ（裏地再建:D）に分類できる。また住宅を撤 去し空地のままの敷地を「未復興タイプ」（空地：E）とした。

復興住宅は、従前の敷地における建物配置を踏襲する形で再建さ れたといえるが、住宅の小規模化や、母屋裏の蔵・納屋等の撤去に より、空地が発生する場合が多く、広い屋敷地の中の空地の利活用、 管理が新たな課題となっている。

現住世帯の場合、（A）が $62.3 \%$ を占めており、（B）が $14.8 \%$ 、 (C) が $13.5 \%$ となっている。その他、(D) が $2.5 \%$ 、(E) が $6.1 \%$ となっている。(C) の内 2 件は、震災後 1 年半時点では (D) に分 類されていた。従前母屋を撤去し、付属棟を改修して復興したが、
その後、母屋跡に小規模母屋を新築した。このことより（D）は（B） （C）に至る途上過程とみることもできる。また、特異事例として （その他 1 ）付属棟跡に小規模の新築母屋が建つ、（その他 2 ）敷地 内に小規模と同規模の新築母屋が建つ、が存在する。

非現住世帯の場合、（E）のタイプが $65.5 \%$ と最も多く、続いて 現状維持（A）が $27.3 \%$ となっている再建の事例は、 4 戸だけで、 従前の棟配置とは無関係に新築母屋が建つ（その他 3 ）の事例は売 却後の所有者が建てた住宅である。

以上から、(その他 3 ) の一事例を除いて、復興住宅は、震災前の 母屋か付属棟の位置で復興・再建されたこと $(\mathrm{A} \cdot \mathrm{B} ・ \mathrm{C} ・ \mathrm{D})$ 、復 興した住宅 $(\mathrm{A} \cdot \mathrm{E}$ 以外 $)$ のほぼ半数は母屋を小規模化して復興 $(\mathrm{C} \cdot$ D）したことがわかった。道下で震災後に小規模母屋が新築された 要因を地元住民に尋衫ると、(1)少ない家族人数に対応させたため、 (2)早期の復興を望んだため、といった回答が挙げられた。

ここで、納屋、蔵、作業小屋、離孔などの付属棟を居室化した例 （D）を紹介したが、これら付属棟は震災後の仮住まい（避難住宅） としても大きな役割を果たしたことを付記しておきたい。

\section{$4-2$. 敷地条件との関連からみた復興住宅の特徴}

表 3 は敷地面積と敷地状況の関係、表 4 は敷地形状と住宅復興夕 イプの関係を示している。

\section{（1）敷地面積との関連（表 3）}

敷地面積が $1000 \mathrm{~m}^{2}$ 以上の場合、再建住宅は小規模である場合が 多く、1000 m²下では従前住宅の規模と同規模のものと小規模なも のはほぼ同数であった。また、大規模な敷地では付属棟が比較的大 きかったため、母屋撤去後に居住棟として利用する事例も見られた。 一方、小規模な敷地では付属棟がない、もしくは小さな付属棟であ る場合が多く、付属棟の居住棟化は見られなかった。また、大規模 な敷地では建物撤去跡を菜園や庭として利用する事例が見られたが、 小規模な敷地ではそのような傾向は見られなかった。

本町通り沿いの敷地では母屋を新築した場合、母屋の前面が駐車 空間となる。一方、北町通り沿いでは母屋の隣が駐車空間となる場 合が多い。これは、北町通り沿いでは母屋の隣に小規模付属棟が建 つ場合が多く、その撤去跡が駐車空間として利用されるからである。

\section{（2）敷地形状との関連（表 4 )}

間口より奥行きが広い整形敷地では、（C）が多く、不整形敷地だ と（B）が多い。また、（D）は奥行きが広い整形敷地のみで見られ たが、このような敷地は集落中心部に多く見られる伝統的形状の敷 地と言える。（D）は道下のもつ敷地形状の特徴を反映した復興パタ

表 3 敷地面積と住宅復興タイプ（敷地状況パターン）の関係

\begin{tabular}{|c|c|c|c|c|c|c|c|c|c|}
\hline & \multicolumn{7}{|c|}{ 敷地状況パターン } & \multirow{2}{*}{ 計 } \\
\hline & & A & $\mathrm{B}$ & $\mathrm{C}$ & $\mathrm{D}$ & $E$ & その他1 & その他2 & \\
\hline \multirow{6}{*}{$\begin{array}{l}\text { 敷 } \\
\text { 地 } \\
\text { 面 } \\
\text { 㳳 }\end{array}$} & $101 \sim 200$ & 3 & 2 & 0 & 0 & 1 & 0 & 0 & 6 \\
\hline & $201 \sim 300$ & 20 & 3 & 4 & 0 & 3 & 0 & 0 & 30 \\
\hline & $301 \sim 400$ & 24 & 5 & 5 & 1 & 5 & 0 & 0 & 40 \\
\hline & $401 \sim 500$ & 28 & 7 & 5 & 0 & 3 & 0 & 1 & 44 \\
\hline & $501 \sim 600$ & 20 & 3 & 1 & 1 & 2 & 0 & 0 & 27 \\
\hline & $601 \sim 700$ & 17 & 4 & 4 & 1 & 0 & 0 & 0 & 26 \\
\hline \multirow{4}{*}{$\mathrm{m}^{2}$} & $701 \sim 800$ & 15 & 2 & 2 & 0 & 0 & 0 & 0 & 19 \\
\hline & $801 \sim 900$ & 8 & 4 & 3 & 1 & 0 & 0 & 0 & 16 \\
\hline & $901 \sim 1000$ & 3 & 1 & 0 & 1 & 0 & 1 & 0 & 6 \\
\hline & $1001 \sim$ & 14 & 5 & 9 & 1 & 1 & 0 & 0 & 30 \\
\hline & 計 & 152 & 36 & 33 & 6 & 15 & 1 & 1 & 244 \\
\hline
\end{tabular}


表 4 敷地形状と住宅復興タイプ（敷地状況パターン）の関係

\begin{tabular}{|c|c|c|c|c|c|c|c|c|c|c|}
\hline & \multicolumn{7}{|c|}{ 敷地状況パターン } & \multirow{2}{*}{ 計 } \\
\hline & & & A & $B$ & C & D & $\mathrm{E}$ & その地1 & その他2 & \\
\hline \multirow{4}{*}{$\begin{array}{l}\text { 敷 } \\
\text { 地 } \\
\text { 形 } \\
\text { 状 }\end{array}$} & \multirow{3}{*}{$\begin{array}{l}\text { 整 } \\
\text { 形 }\end{array}$} & 間口う奥行 & 11 & 5 & 1 & 0 & 3 & 0 & 0 & 20 \\
\hline & & 間口<奥行 & 83 & 17 & 22 & 6 & 5 & 1 & 1 & 135 \\
\hline & & 間口>奥行 & 3 & 0 & 2 & 0 & 1 & 0 & 0 & 6 \\
\hline & \multirow{2}{*}{\multicolumn{2}{|c|}{$\begin{array}{l}\text { 不整形 } \\
\text { 計 }\end{array}$}} & 55 & 14 & 8 & 0 & 6 & 0 & 0 & 83 \\
\hline & & & 152 & 36 & 33 & 6 & 15 & 1 & 1 & 244 \\
\hline
\end{tabular}

表 5 前面道路と住宅復興タイプ（敷地状況パターン）の関係

\begin{tabular}{|c|c|c|c|c|c|c|c|c|c|}
\hline & \multicolumn{7}{|c|}{ 敷地状況パターン } & \multirow{2}{*}{ 計 } \\
\hline & & A & $B$ & $\mathrm{C}$ & $\mathrm{D}$ & $E$ & その他 1 & その他2 & \\
\hline \multirow{4}{*}{$\begin{array}{l}\text { 前 } \\
\text { 面 } \\
\text { 道 } \\
\text { 路 }\end{array}$} & 本町通り & 33 & 8 & 12 & 3 & 4 & 0 & 0 & 60 \\
\hline & 宮町通り & 25 & 6 & 3 & 1 & 1 & 0 & 0 & 36 \\
\hline & 北町通り & 18 & 6 & 9 & 0 & 1 & 0 & 1 & 35 \\
\hline & その他 & 76 & 16 & 9 & 2 & 9 & 1 & 0 & 113 \\
\hline & 計 & 152 & 36 & 33 & 6 & 15 & 1 & 1 & 244 \\
\hline
\end{tabular}

表 6 家族人数と住宅復興タイプ（敷地状況パターン）の関係

\begin{tabular}{|c|c|c|c|c|c|c|c|c|c|}
\hline & \multicolumn{7}{|c|}{ 數地状況パターン } & \multirow{2}{*}{ 計 } \\
\hline & & A & $\mathrm{B}$ & $\mathrm{C}$ & D & $E$ & その他1 & その他2 & \\
\hline 家 & 1人 & 40 & 10 & 16 & 3 & 8 & 0 & 0 & 77 \\
\hline 族 & 2 人 & 65 & 12 & 13 & 2 & 6 & 0 & 1 & 99 \\
\hline 人 & 3人以上 & 47 & 13 & 4 & 1 & 1 & 1 & 0 & 67 \\
\hline 数 & 不明 & 0 & 1 & 0 & 0 & 0 & 0 & 0 & 1 \\
\hline & 計 & 152 & 36 & 33 & 6 & 15 & 1 & 1 & 244 \\
\hline
\end{tabular}

表 7 世帯主年齢と敷地状況パターンの関係（一人暮らし世帯）

\begin{tabular}{|c|c|c|c|c|c|c|c|}
\hline & \multicolumn{5}{|c|}{ 敷地状況ハイターン } & \multirow{2}{*}{ 計 } \\
\hline & & A & B & C & D & E & \\
\hline \multirow{8}{*}{$\begin{array}{l}\text { 世 } \\
\text { 帯 } \\
\text { 主 } \\
\text { 年 } \\
\text { 齡 }\end{array}$} & 40代 & 0 & 0 & 0 & 1 & 0 & 1 \\
\hline & 50 代 & 5 & 1 & 2 & 0 & 2 & 10 \\
\hline & 60 代 & 5 & 0 & 0 & 0 & 0 & 5 \\
\hline & 70 代 & 17 & 4 & 10 & 0 & 0 & 31 \\
\hline & 80代 & 7 & 5 & 4 & 2 & 3 & 21 \\
\hline & 90代 & 2 & 0 & 0 & 0 & 0 & 2 \\
\hline & 100代 & 1 & 0 & 0 & 0 & 0 & 1 \\
\hline & 不明 & 3 & 0 & 0 & 0 & 3 & 6 \\
\hline & 計 & 40 & 10 & 16 & 3 & 8 & 77 \\
\hline
\end{tabular}

ーンと考えられる (表 5 参照)。

\section{（3） 前面道路との関連（表 5)}

前面道路との関連をみると、江戸時代に計画的に形成されたエリ アである本町通りで再建された住宅の小規模化の傾向が強い。それ に対して江戸期の計画エリア以外（その他）では、同規模再建の住 宅が小規模再建よりも多い。

\section{4-3. 家族人数、世帯主年齢との関係}

家族人数、世帯主年齢と住宅の復興状況について整理する。

家族人数に着目すると、表 6 より 1 人暮らし世帯に小規模再建 $(C 、$ D）が多いことがわかった。また 1 人暮らし世帯の中でも世帯主年 齢に着目すると、70 歳代で小規模再建（C）の割合が 7 割と高くな っている。これらの結果より高齢化・家族人数と復興住宅の規模に は密接な関係があることがわかった。（表 6 、表 7 参照）

\section{4-4. 復興住宅の事例}

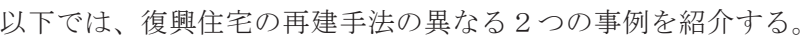

【再建 : S 邸】(図 10. 図 11、写真 3 )

この事例は、本町通り・東町に位置する $\mathrm{S}$ 邸で、全壊した住宅を 撤去し、母屋の位置に住宅を新築したものである。母屋の隣にある
付属棟は納屋であり、現存している。震災以前より一人暮らしの高 齢女性 $\mathrm{S}$ さんの復興プロセスは表 8 の通りである。

$\mathrm{S}$ さんが震災以前に住んでいた母屋（写真 2 参照）は昭和 6 年に 建てられたもので、木造 2 階建ての比較的大規模なものであったが、 震災後に新築された母屋（写真 3 参照）は木造平屋の小規模なもの であった（図 10 参照）。

しかし単に小規模化したのではなく、親族の帰省時を考慮して平

表 8 高齢独居女性 S さんの復興プロセス

\begin{tabular}{|c|c|c|c|}
\hline 年 & 月 & Sさんの動向 & 住宅状況 \\
\hline \multirow[t]{6}{*}{2007} & 3 & 避難所（諸岡公民导館） & \multirow[t]{3}{*}{ 震災により全壊 } \\
\hline & 4 & \multirow{4}{*}{$\begin{array}{c}\text { 輪島で生活 } \\
\text { (娘の元) }\end{array}$} & \\
\hline & $-\frac{5}{6}$ & & \\
\hline & $-\frac{9}{7}$ & & 个 \\
\hline & $-\frac{8}{0}$ & & 再建中 \\
\hline & 10 & 道下几戻る & \\
\hline
\end{tabular}

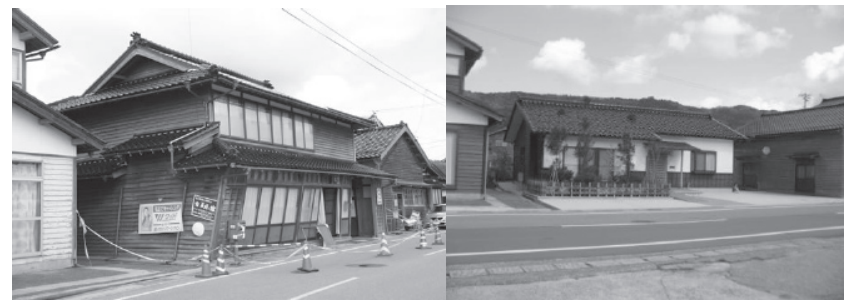

写真 2 震災直後の S 邸

写真 3 震災 2 年後の $\mathrm{S}$ 邸
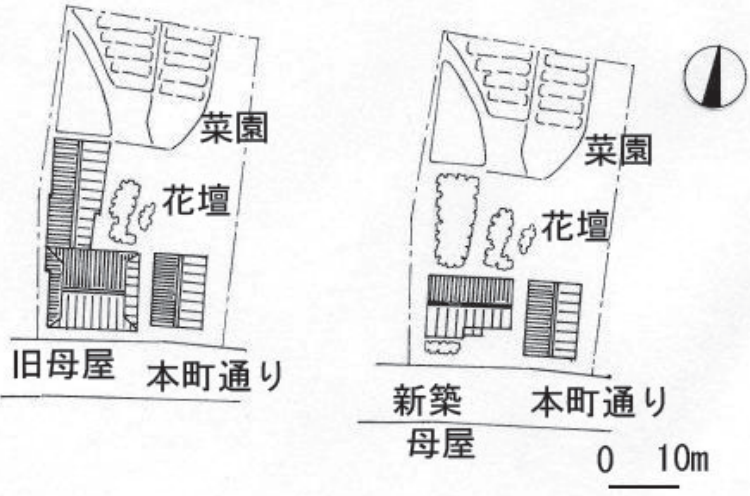

図 10 震災前 (左) と震災後 (右)の S 邸の棟配置

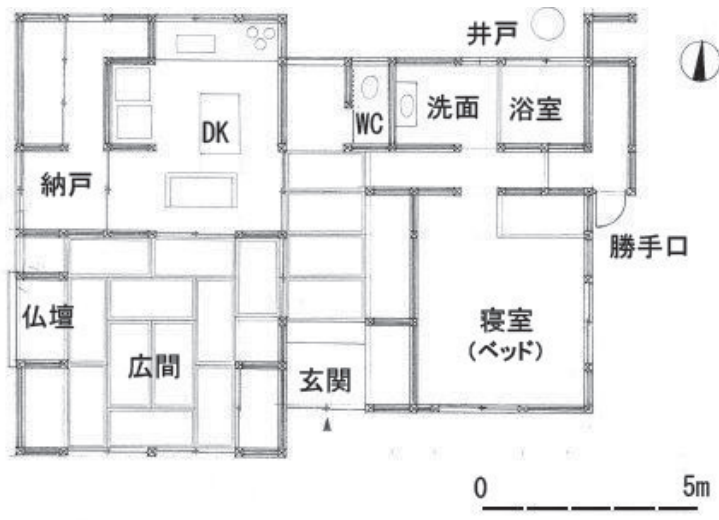

図 11 S 邸の平面図：再建された小規模母屋 
面計画がなされている。広間（和室）であるが、これは帰省した親 族の寝室として設けたと言う (図 11 参照)。実際、2007 年の正月 には 10 人の親族が $\mathrm{S}$ さん宅に宿泊した（広間 6 人、DK1 人、納戸 1 人、寝室 2 人)。 $\mathrm{S}$ さん宅のような「母屋の小規模化」が道下の住 宅復興の大きな特徴である。

この住宅は、盆正月の親族の帰省、近隣の親戚・友人の来訪や、 祭や法事一の対応、仏壇・神棚の設置にも配慮された造りになって いる。広間には仏壇が置かれ、本通りに面して雪見障子のはいった 引き違い戸、広い立関が設けられており、表通りを意識した住宅造 りとなっている。これは夏祭りの際に広間に飾る御供に象徵される。

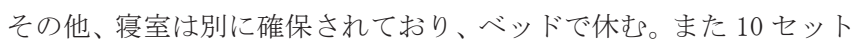
以上の布団を収納するスペースが設けられている。

この住宅は、輪島市がモデル住宅（能登ふるさとモデル住宅）注 6) を示寸前に建設されたものであるが、平屋、瓦屋根、外装は下見板 貼りで、地域の伝統的な住宅デザインを継承するものになっている。

母屋が小規模化することによって屋敷地内のオープンスペースが 増大寸ることになる。この家では当初菜園として利用していた土地 の一部に植林し、土地を管理することにしたということだった。

【修理：I 邸】(図 12、写真 4)

第二の事例は、本町通り・中町に面する I 邸で、半壊した母屋を 建て起こしした事例である。震災前の住宅は、伝統的な間取りを継 承するプランで、能登の民家の典型とされる「シロッケン」（4 間 $\times$ 6 間）の間取りにニワがつくタイプである注 7)。本通りに面するミ セ、ザシキは、かつては客を泊めたりした部屋で、接客、冠婚葬祭 に現在でも利用されている。（図 12 参照）

この住宅は、伝統的な間取りを蹈襲しており、震災後に西側の土 間を床上げし、東側の物置を書庫に改装して修理している。工事期 間中は母屋裏の納屋で寝泊りし、入居したのは 7 月上旬であった。

修理後は、表通りに面してミセ（客の間として利用）と座敷が配 され、奥にオエ (居間)、カッテが配されている。2009 年の夏祭り 時には、玄関と座敷が飾り付けられ、本町通りを通る御興（神様） に対して、座敷に御供（御米と御神酒）が供えられていた（写真 4 , 写真 5 参照)。

\section{4-5. 仮設住宅と災害公営住宅について}

震災後約 2 年を経過した 2009 年 4 月 25 日に道下集落の総合健康 増進広場内に建設された仮設住宅は閉鎖された。

道下集落の被災者は、仮設住宅が設置された 2007 年 4 月末には 58 戸が入居し、2008 年 4 月末には 24 戸、2009 年 3 月末の時点で 5 戸が入居していた。残った 5 戸も、既存の松風台住宅に隣接して 2009 年 2 月に建設された災害公営住宅（輪島市の災害公営住宅第 1 号にあたる）に 4 戸、集落内の被災者の所有地に建設された「自己 所有地提供型災害公営住宅」注 6) (参考文献 3) 三谷論文、図 13 参 照)）に 1 戸が入居し、すべての被害者が恒久住宅に居住した。

この時点で、住宅復興は完了したとみることができる。（2009 年 8 月調查時には、（D）の裏再建の事例で、空地になっていた母屋の 跡地に新たに母屋を増築している例も数戸確認できた。）

\section{5.まとめ}

本稿では、道下集落の空間構成の特徵を整理したうえで、震災後 2 年時点での住宅復興の実態とその特徴について考察した。本稿で 得られた知見を以下に整理し、まとめとしたい。

1）道下は江戸時代に整備された本町通り沿道の整然とした屋敷地

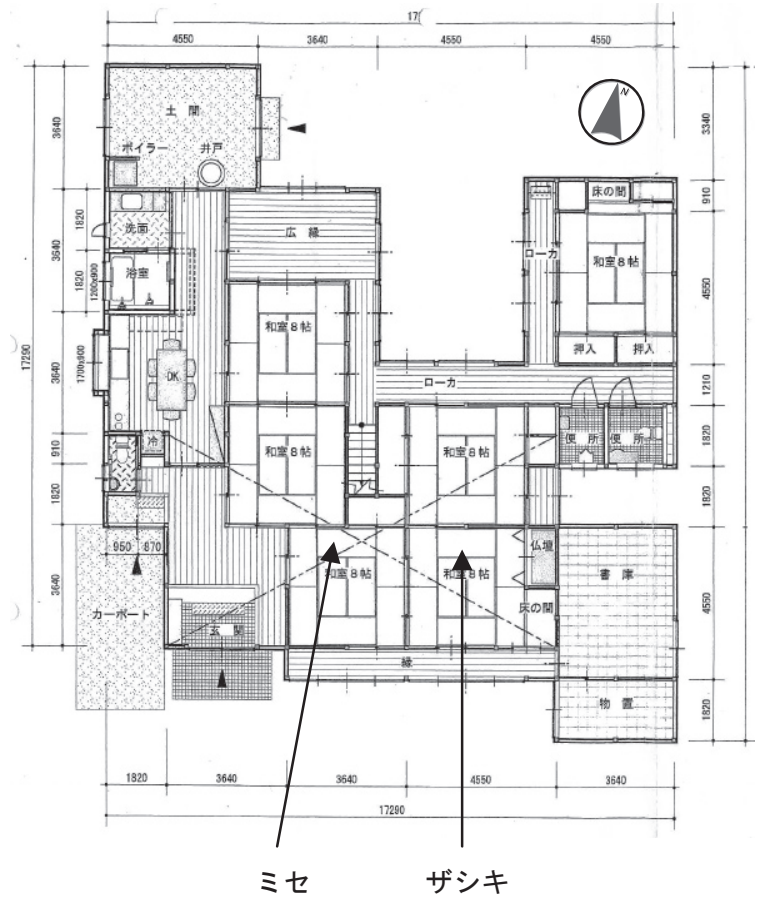

図 12 本町通り中町の住宅の間取り (修理後：I 邸))

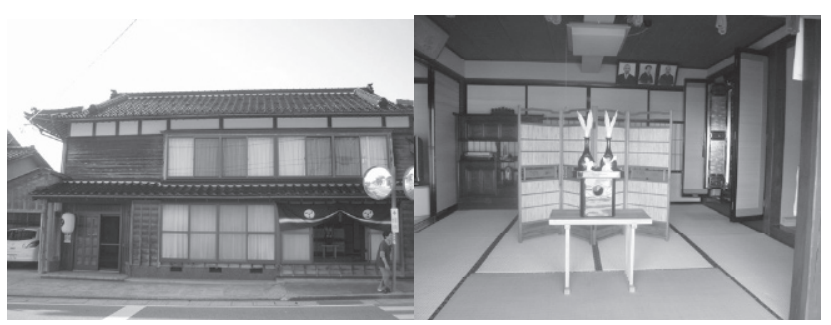

写真 4 夏祭り時の I 邸

(2009. 8)

写真 5 夏祭り時の御供

20080331輪島市都市整備課

自己所有地提供型 災害公営住宅の建設について (自力再建が不可能な高齢者のみ世帯等への支援)

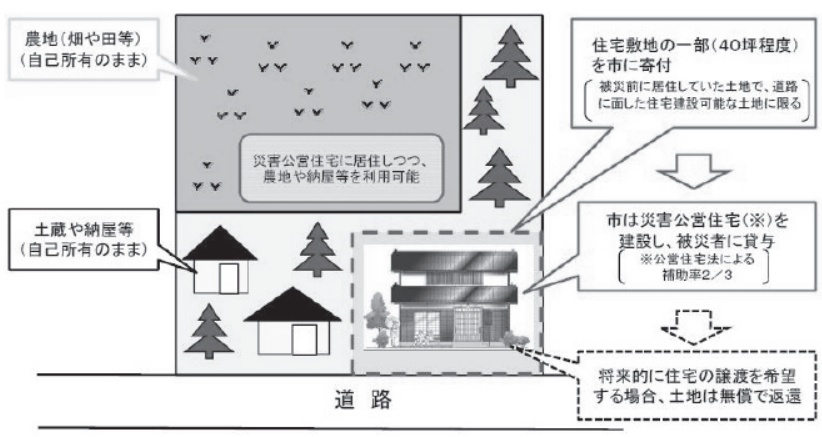

*出典 : 輪島市都市整備課

図 13 自己所有地提供型の災害公営住宅 
に特徴があり、復興後の住宅の配置は、従前の母屋の場所や敷 地パターンと対応していることがわかった。

2 ) 震災後 2 年時点での復興住宅は、住宅の規模と屋敷地の空間構 成の組み合わせから、次の 5 タイプに整理できた。

（A） 従前母屋が解体されずに建つ場合一修理、増築による復興、

（B）従前母屋跡に同規模の新築母屋が建つ場合、

（C）従前母屋跡に小規模の新築母屋が建つ場合、

（D）従前母屋を撤去し付属棟を改修して居住棟とする場合、

（E）母屋を撤去し、空地のままである場合、

3 ) 居住者の居住状況（現住、非現住）、家族タイプ（世帯主年齢、 家族数）や敷地の相違によって住宅復興の特徵も異なることが わかった。

現住と非現住では、住宅復興のタイプは大きく異なり、現住では 修理による復興（従前母屋を維持して住宅復興：(A）タイプ）が約 6 割に対して、非現住では、母屋を撤去して更地にしたものが $65 \%$ を占めている。

現住の母屋撤去の場合、従前の母屋の位置に住宅を再建した事例 がほとんどであり (69/71)、従前の建物配置・屋敷地利用パターン を継承した復興となっている。

復興住宅の規模に着目すると、同規模の母屋を再建したものが 36 、 小規模な再建が 33 であること、70 歳代の独居では約 7 割が小規模 再建となっており、高齢化と復興住宅の規模には密接な関係がある ことがわかった。

敷地面積との関連に着目すると、1000 $\mathrm{m}^{2}$ を越える敷地で (C) が 多く見られ、300 $\mathrm{m}^{2}$ 以下の小規模敷地では（D）が見られない等、 震災後の敷地状況と敷地規模には関連があることがわかった。また、 奥行の広い整形敷地で（C）（D）が見られる等、震災後の敷地状況 と敷地形状には関連があることが示せた。

4 ）住宅復興タイプ別の 2 年間の再建率が示せた。

震災後 2 年時点でほぼ住宅復興は完了したといえ、 2 年間の住宅 の「再建」、「修理」のタイプ毎の復興状況（再建率）を震災半年、 初めの正月、震災後 1 年、震㷋後 1 年半、震災以後 2 年での再建率 (復興率) として示せた。

再建と修理では復興のスピードが異なり、半年後で再建は $30 \%$ 、 修理は 84\%、正月前で再建は 50\%、修理は 99\%、1 年後では再建 $64 \%$ 、修理は $99 \%$ 、1 年半後で再建は $70 \%$ 、修理は $100 \% 、 2$ 年後 で再建は $83 \%$ 、修理は $100 \%$ となっている。

道下集落の住宅復興は、全体として迅速で、大規模損壊・全壊住 宅の新築による復興率は被災 2 年時点では約 8 割が復興し、修䋨の 場合だと被災 1 年でほぼ $100 \%$ の住宅が復興したことがわかった。

本稿では、道下集落の現住世帯を中心に震災後 2 年時点での住宅 復興の実態について報告した。しかし過疎高齢化の著しい道下集落 の復興では、非現住世帯の空地問題が大きな課題注8) となっており、 その点については次稿で報告したい。

また公的な復興政策と住宅復興の関係や復興住宅のプラン・ファ サードの評価、生活復興のプロセスの解明も残された研究課題であ る。道下集落に隣接する漁村の鹿磯や伝建に指定された黒島の復興 についても復興調查を継続している。第 1 報注 9) でふれたが隣接す る鹿磯集落の住宅復興の進渉は遅く、復興される住宅も規模が大き
い。道下集落の復興の性格を明確にする上でも、周辺集落との比較 も今後の研究課題としたい。

\section{謝辞}

本研究を行うにあたり、輪島市門前町諸岡地区道下区の泉靖郎区 長、門前町郷土史研究会の佃和雄会長、大倉克男代表幹事、調査に 協力いただいた諸岡地区の皆様、輪島市都市整備課、石川県建築住 宅課に多大なるご協力を戴いた。記して謝意を表する次第である。

また現地調查、収集資料整理、作図作業については、神戸大学大 学院の金斗煥君にお世話になった。この場を借りて謝意を表する。

注

注 1 ) 山崎寿一: 能登半島地震被災集落・道下の地域性と震災復興、日本建築 学会計画系論文報告集、第 74 巻、第 646 号、pp2617-2626, 2009.12

注 2$) 1$ 回調查 $(2007$ 年 5 月、震災 1 ヶ月)、第 2 回 $(2007$ 年 9 月、震災 6 ヶ 月)、第 3 回 $(2007$ 年 11 月、諸岡地区住まい・まちづくり協議会設立 1 ケ月)、第 4 回 (2007 年 12 月、正月前)、第 5 回（2008 年 4 月、震災 1 年)、第 6 回 $(2008$ 年 8 月、震災 1 年 6 ケ月)、第 7 回 (2009 年 1 月、震 災 1 年 6 ケ月調查の補足)、第 8 回 (2009 年 3 月、震災 2 年)、第 9 回 (2009 年 4 月、震災 2 年 2 次)、第 10 回 $(2009$ 年 7 月・ 8 月、震災 2 年 4 ヶ月、 夏祭り調查)。第 1 回調查は、日本建築学会農村計画委員会（伊藤庸一委 員長）の視察調查。他は、神戸大学山崎研究室としての調查である。山 崎は、2007 年 9 月より 2009 年 3 月までは、輪島市震災復興計画諸岡地 区アドバイザーとして復興計画に関与した。

注 3 )参考文献 1 ）参照。ここでは、道下集落の地域特性を、以下のように整 理している。(1)能登半島地震最大の被災地である。(2)住宅復興のスピー ドが速く、復興が極めてスムーズに進んだ被災地である。(3)過疎化・高 齢化・小家族化が著しい奥能登地域の農村集落である。(4)輪島市 181 集 落のうち、最大規模（戸数約 300 戸）の集落で、旧門前町諸岡地区の中 心集落である。(5)江戸時代宝明年間の大火以降に計画的な宅地割、道路 建設された集落であり、近世以降に形成された集落基盤（道路、宅地割 の基本骨格）が現在に至るまで継承されている。(6)数代、十数代にわた って道下で定住する家が確認でき、集落維持に対する意識も高い定住社 会を形成している。

注 4 ) 黒島の復興計画は、伝建保存対策調查（委員長 土屋敦夫 滋賀県立大 学）と一体的に進められた点で特徴がある。

注 5)「天明年間に 2 度の大火があったため、旧村から新しい村造りを始めて 移住したと伝える。現在の道下の町並みはこの時以来のもので、火災を 恐れて延焼防止のため広い敷地を各戸とも設けることにしたと云う。」 石川県教育委員会、石川県の民家一民家緊急調查報告書（p37）、1972 注 6) 2007 年 11 月に地元に公表。参考文献 4）参照

注 7)参考文献 1） 2）参照

注 8) 参考文献 4) 参照

注 9) 輪島市都市整備課の 2008 年 8 月時点の集計によると、鹿磯集落の復興 率は約 3 割。

\section{参考文献}

1))諸岡村史編集委員会：諸岡村史、1977

2) 石川県教育委員会 : 石川県の民家一民家緊急調查報告書、1972

3)三谷浩二郎（石川県建築住宅課、元輪島市都市整備課、）：住まい・まちつ くりの復興に向けて一輪島市の取り組みー、石川建築士、134 号、2008

4) 金斗煥・山崎寿一：能登半島地震・被災集落における居住者動向と空地の 管理・活用課題一輪島市門前町諸岡地区道下の場合一日本建築学会住宅系 研究報告会論文集 $3, p p 133-140,2008.12$

（2009年11月10日原稿受理，2010年 1 月18日採用決定） 